\title{
Mestiçagens de um butô negro: colorações afro-brasileiras na dança de Marco Xavier
}

\author{
Flávio Tonnetti \\ Universidade Federal de Viçosa (UFV) \\ Sandra Corradini \\ Universidade Federal da Bahia (UFBA) \\ Simone Mello \\ Universidade Federal da Bahia (UFBA)
}

\begin{abstract}
Resumo
Este ensaio discute um conjunto de questões provocadas pela obra do bailarino brasileiro Marco Xavier, articuladas a partir de perguntas geradoras tecidas por meio de uma correspondência estabelecida entre o artista e três pesquisadores no campo da dança e da performance. O diálogo transita em torno da presença do corpo negro e da espiritualidade afro-brasileira numa dança concebida em uma cultura de corpos amarelos, evocando os temas da mestiçagem e da resistência frente à necropolítica, discutindo aproximações e diferenciações entre o contexto social, histórico e cultural japonês - no qual se dá a gênese do Butô pela emergência de um corpo ritualizado e violentado, inadequado e marginal - e o contexto histórico e religioso brasileiro - dentro do qual o corpo negro permanece como um corpo à margem.
\end{abstract}

Palavras-Chave: Butô afro-brasileiro; mestiçagem; dança contemporânea; Marco Xavier.

\section{Cores Proibidas}

Uma flor que no chão cai

E retorna à ramada - que nada!

Borboleta leve vai...

Arakida Moritake $^{1}$

Um homem negro, completamente trajado de branco, executa os movimentos mínimos de uma dança amarela. Recolhido sobre si mesmo, vai se erguendo aos poucos: faz um balançar discreto - quase imperceptível - enquanto seu corpo deixa crescer uma sombra sobre um fundo animado. Nele, vemos sobreposições de imagens de células neurais, representações de galáxias e formas orgânicas com um discreto sabor psicodélico. Lentamente, seus movimentos ganham mais amplitude, na dimensão discreta de quem entra em transe. Move-se mais o mundo ao seu redor do que o sujeito que habita dentro dele. Ao

\footnotetext{
${ }^{1}$ Arakida Moritake (1473 - 1549), sacerdote xintoísta, é um famoso poeta de haikais do período clássico japonês. Poema original: rakka eda ni / kaeru to mireba / koch kana. Transcriação para o português por Flávio Tonnetti.
} 
longo dessa dança, vai deixando cair do corpo folhas de plantas diversas, que trazia ocultas em suas vestimentas brancas. Como uma espécie de haikai dançado, esse rito outonal nos permite sentir algo sobre o nascimento e a morte, na gênese de um butô afro-brasileiro.

Obra do bailarino Marco Xavier ${ }^{2}$ (1958), essas sensações compõem o solo Pequenos Sonhos das Folhas Vermelhas - ou simplesmente Folhas - uma performance butô apresentada no Brasil e no exterior durante os últimos anos por um artista que começa sua carreira em grupos de danças populares e de danças afro até se firmar no campo das artes performáticas como bailarino de dança contemporânea. Sua formação em danças populares, em que temos a improvisação e a adaptação aos ambientes, como dinâmicas inerentes à construção das performances, revela-se muito bem em Folhas, uma obra que vai sendo ligeiramente ajustada e adaptada aos locais e contextos nos quais se apresenta - o que nos permite caracterizá-la tanto como um work in progress quanto como uma obra aberta.

Ao considerar as possibilidades de sentido que vai assumindo ao longo dessas mutações, esse trabalho acaba por evocar a própria gênese do butô no Japão; mais especificamente a performance Kinjiki - Cores Proibidas - que Tatsumi Hijikata (1928-1986) apresentou num festival japonês de dança em maio de 1959, e que é frequentemente citada como momento seminal do butô (WEIR, 2015; GREINER, 2005). O nome do espetáculo de Hijikata é inspirado na novela homônima escrita por Yukio Mishima em 1951, um escritor igualmente obcecado pela morte e assombrado pela guerra (UNO, 2018, p. 178) e cuja obra também trata de temas tabus relacionados à sexualidade. Ainda que seus propósitos estéticos, filosóficos e artísticos não estivessem necessariamente alinhados, Hijikata encontra em Mishima a fissura cultural para que os afetos do corpo possam ser debatidos no interior da própria cultura japonesa.

Desde sua gênese, o que o butô nos mostra é a manifestação de corpos que se sentem inadequados numa realidade em ruínas. Além das sequelas imediatas da Segunda Grande Guerra, Yoshito Ohno, que contracenou com Hijikata nessa estreia, nos lembra das condições impostas pelo frio e pela fome que caracterizavam o contexto japonês nesse momento em que o butô surgia: "o clima não era o mesmo de hoje - era mais frio e nevava. Hoje em dia ninguém morre de fome. $O$ frio e a fome são elementos críticos para as pessoas pensarem no corpo". E relembra o que Hijikata lhe dizia nos anos 60: "não é fácil viver a vida; se você não encarar as dificuldades, não estará qualificado para fazer butô" (OHNO, 2003). O butô, dessa forma, se insere numa cultura japonesa historicamente marcada pelo imaginário da catástrofe (CUNHA, 2020).

\footnotetext{
${ }^{2}$ Xavier iniciou sua carreira de dançarino em 1987, em grupos com Tião Carvalho e Marcelo M'Dambi. Foi aluno de José Ordonez, Mariana Muniz, Macalé dos Santos, Mestre King, Negrizu Santos, Rosangela Silvestre, José Maria Carvalho, Denilto Gomes e Maria Mommensohn.
} 
Yoshito relata, ainda, que havia na cultura japonesa um complexo vivido pelos japoneses em relação ao corpo ocidental, dando pistas para a problemática identitária em jogo no Japão do pós-guerra. Essa percepção de habitar um corpo inadequado e ameaçado é reforçada pela dimensão homoerótica do espetáculo ${ }^{3}$, o que nos ajuda a compreender 0 butô como resposta artística contra uma realidade que é em si hostil e violenta - não apenas materialmente, mas também culturalmente. $O$ que se procura discutir, portanto, são temas interditos e velados, bem expressos na ideia de "proibição" presente no título do espetáculo seminal que inaugura o butô como gênero da dança.

Se tomamos o trabalho de Xavier como uma elaboração artística que põe em evidência, de forma arquetípica, um corpo ameaçado e excluído, fica mais fácil perceber a aproximação com Hijikata. Tal aproximação nos permite pensar de que forma cada um desses artistas compõe sua arte como reação a um regime de necropolítica que impede a experiência da realização do sujeito a partir de seu próprio corpo, que é visto - cada qual na cultura em que habitam - como um corpo marginal ou proibido. Isso porque ambas as performances, a do corpo japonês de Hijikata e a do corpo afro-brasileiro de Xavier, expõem corpos material e espiritualmente marginalizados - ainda que em diferentes medidas e em contextos temporal e culturalmente distintos.

No caso de Hijikata, temos a experiência de um corpo japonês aniquilado pela Grande Guerra, agora atravessado pela cultura norte-americana, que necessita se reinventar em meio a ruínas que o impedem de continuar a ser o que se era: corpo amarelo ${ }^{4}$. No caso de Xavier, temos um corpo afro-brasileiro historicamente violentado que precisa resistir à construção de muros que o impedem de vir a ser do jeito que se é: corpo negro.

Cada qual a seu modo, corpo japonês e corpo afro-brasileiro, colocam em questão a violência contra uma cor de pele específica e um jeito de ser de um corpo. É como se estes corpos buscassem exprimir, através de uma performatividade estética, suas estratégias subjetivas de afirmação que acabam por se configurar na forma de uma dança, numa práxis que pode ser expressa artisticamente.

Essa nova práxis do corpo desenvolvida por Hijikata tornou visível alguns mecanismos sutis de resistência física e simbólica que até então habitavam a intimidade de seu corpo, imerso em um constante processo de busca pela

\footnotetext{
${ }^{3}$ Perguntado sobre suas memórias em relação ao espetáculo Kinjiki, Yoshito responde: "Quando começamos a ensaiar, Hijikata não explicou nada; me dizia somente 'enrijeça o seu corpo e fique em pé', 'ande, apenas'. Estava perdido, pois era a primeira vez que fazia algo assim. Duvidava do que fosse, mas era capaz de segui-lo naturalmente. Depois perguntei o que a peça significava, e ele respondeu que era sobre um relacionamento" (OHNO, 2003, s/p). Thiago Abel e Daniel Aleixo (2020) indicam que o título original Kinjiki pode ser traduzido do japonês como "desejos proibidos", com sentido de desejos vulgares, imorais ou sórdidos. Centonze, investigadora do butô, propõe como tradução a expressão "prazeres proibidos", ampliando as possibilidades de compreensão do termo (PERETTA, 2015, p. 50).

${ }^{4}$ Sobre a poética de Hijikata e sua relação com o contexto histórico japonês em que se dá o surgimento do butô, ver a pesquisa de Bárbara de Souza Carbogim (2016, p. 63).
} 
sobrevivência às margens de uma sociedade destruída e violentada pelas novas imposições culturais do Ocidente. (PERETTA, 2015, p. 144).

A própria noção de treino, termo que tanto seus fundadores (OHNO, 2016) quanto seus continuadores (ALISHINA, 2015) invocaram para se referir à preparação do corpo para a realização do butô como dança, aponta para a noção de resistência. É preciso preparar o corpo para garantir sua performance, para impor sua presença como fato inaugural, e disruptivo, em oposição a uma cultura tradicional, a fim de permitir, ao sujeito que dança, realizar-se como existência singular.

Nessa perspectiva, por seu modus operandi, o butô se apresenta como território de um corpo que se recusa a uma lógica dicotômica que opõe o ser ao não ser. Não se trata de ser ou não ser japonês, de ser ou não ser ancestral, de ser ou não ser uma dança, mas de ser e não ser tudo o que se pretende afirmar e negar. Sua ousadia vai, justamente, contra a impossibilidade de se criar um terceiro modo de ser - que, em termos lógicos, deixa de ser um terceiro excluído e passa a ser um terceiro instruído. É justamente esse sentido de deslocamento, de síntese e de invenção que caracteriza o butô como a realização, no corpo, de um pensamento mestiço (SERRES, 1993), permitindo que possa ser caracterizado como uma dança da diferença (BAIRD, 2019).

\section{Cores Próprias}

Quero ser negro $100 \%$, americano

Sul-africano, tudo menos o santo Que a brisa do Brasil, briga e balança

$E$, no entanto, durante a dança Depois do fim do medo e da esperança Depois de arrebanhar o marginal, a puta O evangélico e o policial Vi que o meu desenho de mim É tal e qual O personagem pra quem eu cria que sempre Olharia

Com desdém total Mas não é assim comigo É como em plena glória espiritual Que digo:

Eu sou o homem cordial Que vim para instaurar a democracia racial

Eu sou o herói

Só Deus e eu sabemos como dói

Caetano Veloso

Se tomamos o pensamento mestiço de Michel Serres, expresso por Marco Xavier ao refletir sobre sua própria obra, podemos observar como vão se deslocando e entrelaçando as fronteiras da arte, permitindo, no caso específico de Xavier, pensar o butô como práxis da 
constituição de corpos síntese, na tradução de uma dança que representa a junção de uma ancestralidade singular a uma modernidade global, na combinação do que pode ser tradição com o que pode ser contemporaneidade e na fusão entre elementos orientais e ocidentais. Nesse entrecruzamento, reforçado pelas transmutações inerentes ao próprio butô, talvez possamos pensar os efeitos do deslocamento de sua cultura de origem para uma outra cultura síntese, como é o caso da cultura brasileira, observando quais elementos podem ser revelados nessa fusão-fissão, em que o que foi amalgamado se reconhece como múltiplo na experiência de um olhar analítico. Essa perspectiva de síntese dialoga não apenas com a noção de mestiçagem de Serres (1993) ou com hibridismo de Canclini (1995), conhecidos pelo tratamento dado aos encontros entre culturas, mas, sobretudo, com a posição de Darcy Ribeiro (1995) no que diz respeito à formação cultural do povo brasileiro, compreendida como resultado da combinação de diferentes matrizes culturais na formulação de uma identidade paradoxalmente singular e múltipla. Todas essas perspectivas conceituais de algum modo nos apresentam novas perspectivas epistemológicas para que possamos lidar com a crise da racionalidade instrumental contemporânea, a mesma por meio da qual se produziu tanto a catástrofe da colonização quanto a das armas de destruição em massa.

Não devemos, portanto, confundir a noção de pensamento mestiço de Serres com uma determinada noção de mestiçagem à brasileira. Isto porque, no primeiro caso, o que se pretende é afirmar a potência da multiplicidade a partir do reconhecimento de cada singularidade que a compõe, observando o resultado desse sincretismo, enquanto, no segundo, o que se produz é uma tentativa de apagamento, silenciamento ou branqueamento 5 . A ideia de democracia racial permanece no Brasil como um mito - como denuncia a canção O Herói de Caetano Veloso - usado para mascarar uma realidade de sofrimento, exclusão e dor vivida por aqueles cujos corpos não são brancos. Violência essa que tem, historicamente, se realizado como um genocídio - derivado do racismo estrutural e da necropolítica vigentes no Brasil (ALMEIDA, 2019).

Como signo de resistência, podemos observar de que forma um conjunto de determinados elementos de uma ancestralidade afro-brasileira se combinam, na obra de Xavier, a uma linguagem contemporânea que expressa o peso de ser negro no Brasil. O butô oferece, como gênero, uma linguagem propícia para o tratamento dessas questões. $\mathrm{Na}$ transposição da cultura japonesa para a brasileira, podemos ver quais escolhas e combinações são operadas na elaboração de um butô coreografado por um artista afrobrasileiro ${ }^{6}$, não apenas para pensar as singularidades do butô, mas para observar de que

\footnotetext{
5 Sobre essa discussão em torno do uso do conceito mestiçagem na sociologia brasileira, vale a pena consultar o texto referencial de Kabengele Munanga: Rediscutindo a mestiçagem no Brasil: identidade nacional versus identidade negra (MUNANGA, 1999).

${ }^{6}$ Uma discussão sobre a definição de arte afro-brasileira é feita por Kabenguele Munanga (2000). Articulado a outros autores, o texto de Munanga é retomado por Francione Carvalho, Matheus Assunção e Karina da Silva
} 
forma uma dança oriental permite que determinadas raízes - muitas vezes ocultas; ou soterradas - da cultura brasileira sejam reveladas e potencializadas. Nos interessa pensar, então, de que forma esse butô-brasileiro se apresenta, no caso de Xavier, como um butô afrobrasileiro, ou como um butô negro, a partir do qual as noções de Oriente e Ocidente assumem novos contornos. Nessas flutuações do butô de uma tradição a outra, vemos como a mística religiosa, que no Japão se dava na chave do xintoísmo - religião marcada pela intensa relação com elementos da natureza - se move para o interior das religiões sincréticas brasileiras derivadas das matrizes africana e indígena.

Os cultos que se dão em comunhão com elementos da natureza, na integração do humano com seu meio - dimensão presente na obra de Xavier - compõem parte importante da ritualística das religiões afro-brasileiras, inclusive como signo de resistência contra uma realidade catastrófica. A experiência da catástrofe, reelaborada pelos criadores do butô a partir do imaginário japonês, também se apresenta para aqueles que habitam o território brasileiro como corpos excluídos - como ocorre, no recorte racial, com corpos negros e indígenas - afinal, vivemos no interior de uma cultura marcada por aquilo que Ailton Krenak denunciou como uma "experiência do desastre" (KRENAK, 2020).

Não é trivial que possamos trazer para nossa discussão a posição de Krenak. Como uma das maiores lideranças do movimento indígena brasileiro, foi testemunha e vítima direta de um dos maiores crimes ambientais do planeta - quando uma barragem de empresas de mineração se rompeu no município de Mariana, em Minas Gerais, afetando a bacia hidrográfica do Rio Doce e ceifando um imenso ecossistema que dava suporte a todos que viviam nesse território. Sua condição é, portanto, paradigmática para pensarmos o regime de necropolítica brasileiro. Isso nos dá a dimensão do problema enfrentado por esses corpos: não se trata apenas de uma questão histórica ou "do passado", mas de processos sociais que continuam a ameaçar fisicamente as identidades de parte significativa da população brasileira.

É preciso lembrar, portanto, que é também no interior dessa cultura de extermínio que Xavier, na condição de negro, ergue sua dança como afirmação da vida apesar da morte. Se "estamos dentro do desastre" sem que dele ninguém nos possa tirar, e se temos que atravessar um deserto em que nada cresce ou se desenvolve, como Krenak profetiza, então, quais tipos de estratégias podemos elaborar para superar essa realidade?

Se a arte for parte dessa resposta, então podemos nos perguntar sobre quais desertos podem ser expressos e atravessados por um butô de corpos negros, que são alvos constantes

(2020) para apresentar uma discussão sobre o conceito de artista afro-brasileiro a partir da produção visual de artistas contemporâneos. 
de regimes de necropolítica ${ }^{7}$. Como transmutar a realidade do desastre e do deserto, que se realizam no próprio corpo de carne, como uma expressão de resistência e permanência?

Esses humanos ameaçados - amarelos, negros ou indígenas - compõem um universo em que seus corpos entram em diálogo com corpos de outros seres vegetais e animais igualmente ameaçados. Nos treinos de butô, é comum aparecerem exercícios que buscam estabelecer equivalências do corpo humano com corporeidades vegetais e animais, em exercícios que propõem a interiorização ou transmutação de um corpo em outro (OLIVEIRA, 2009). Essa dinâmica de transmutação ou identificação com outras formas de vida, inerente ao próprio butô, nos permite compreender mais claramente por quais meios ele navega do Japão ao Brasil - o que certamente nos convida a estabelecer paralelos com a visão cosmológica indígena na acepção do perspectivismo ameríndio (CASTRO, 1996). Uma aproximação pertinente para pensar a elaboração coreográfica de Marco Xavier, já que, no contexto sincrético das religiões afro-brasileiras mobilizadas por ele, o componente cultural indígena também aparece, reforçando, na poética brasileira, a partir de novas colorações, algo que já se apresentava no contexto japonês como traço de comunhão com a natureza.

$\mathrm{Na}$ busca dessas conexões, é contra o desastre de um regime de morte que o butô se apresenta como o treino necessário para a travessia do deserto, nos devolvendo a um estado de atenção que nos reconecte com o fluxo da vida. Nesse sentido, como treino ou como práxis, talvez o butô possa nos auxiliar em um processo de reconexão com a terra.

No interior dessa mestiçagem, mais uma vez, o depoimento de Ailton Krenak vem nos socorrer: nos provocando a lançar o nosso corpo de carne de volta ao corpo extenso da terra, ele sugere encontrarmos um lugar onde possamos nos sentir à vontade para nos deitarmos com a pele descoberta em contato direto com um chão vivo, estabelecendo uma espécie de rito. Nos moldes de um mestre de butô, Krenak nos diz: "se essa experiência de misturar isso que é você - ou que você pensa que é você - com a terra, for boa, continue por um pouco mais até a terra falar com você. Ela fala. E o seu corpo vai escutar" (KRENAK, 2020, 00:70:43).

Pelos termos e pela forma como esse exercício se dá, muito facilmente se poderia assumi-lo como um treino de butô, nos moldes daqueles elaborados por Hijikata, Kazuo Ohno (1906-2010) ou Yoshito Ohno (1938-2020). Basta lembrar que "é na lama, nesta força que alude ao mesmo tempo ao útero e à sepultura, que Hijikata fundamentou sua existência e sua arte", pois "sabia que é preciso permanecer fiel à terra, compreendendo a sabedoria trágica anunciada por ela" (ABEL; ALEIXO, 2020, p. 488). Nas palavras do próprio Hijikata:

\footnotetext{
${ }^{7}$ A discussão sobre necropolítica remonta diretamente ao ensaio de Achille Mbembe (2018), em que o autor discute de que modo se organizam os regimes políticos de morte, em que se estabelecem quais corpos podem ser descartados ou mortos. É esse o trabalho que Silvio de Almeida (2019) irá retomar para a discussão sobre o racismo estrutural no Brasil.
} 
O meu butô começou ali com o que aprendi com a lama no início da primavera, não com qualquer coisa que tenha a ver com as artes performáticas de santuários ou templos. Estou perfeitamente ciente de que nasci da lama e que meus movimentos de agora foram todos construídos com base nisso. (HIJIKATA, 2000, p. 74).

\section{Cores Paulistanas}

soando como um shamisen e feito apenas com um arame tenso um cabo e uma lata velha num fim de festafeira no pino do sol a pino mas para outros não existia aquela música

Haroldo de Campos

Expressão altiva e permanente no panorama da dança contemporânea brasileira nestas últimas décadas, o bailarino, ator e músico Marco Xavier tem se dedicado a pensar e a produzir, com o seu próprio corpo, uma interlocução entre a cultura japonesa e a cultura afrobrasileira a partir de um território específico que é altamente propício a essa interlocução: a cidade de São Paulo. Reconhecida pela presença da cultura japonesa decorrente da migração (SUZUKI, 1995), a metrópole paulistana chega a possuir um "bairro japonês" - o bairro da Liberdade - visualmente marcado por um conjunto de elementos arquitetônicos inspirados na estética japonesa (BOCCl, 2009). Paulistano "da gema", Marco Xavier transita por estes espaços, estando imerso num ambiente cultural que absorve essa cultura japonesa e a reconfigura também em outros campos, como nas artes plásticas e na poesia concreta.

É nesse ambiente territorial e cultural metropolitano que Xavier, como diretor da Cia. Paisagens Flutuantes - com sede no Centro Cultural do Jabaquara, um bairro de São Paulo também marcado pela presença japonesa - vai se colocando, desde 2010, tanto como um investigador do butô quanto como obreiro das manifestações culturais de matriz africana, das quais é herdeiro direto. É esse contexto urbano que vai marcando a sua poética através de encontros com outros artistas e linguagens.

Parceiro e colaborador de inúmeros artistas como Denilto Gomes, Takao Kusuno, Key Sawao, Ricardo lazzetta, Patrícia Noronha, Vera Sala, Emilie Sugai, Rosana Ribeiro, Maureen Jones e Simone Mello, entre outros, transita pelos espaços institucionais e simbólicos do que se costuma chamar "arte contemporânea". Trabalhando com uma fusão de linguagens provenientes do teatro, da dança, da performance, das artes visuais, da música e da poesia, Xavier trava contato com artistas e agentes institucionais de outras linguagens além da dança - a exemplo do que fazia Hijikata na gênese do Butô no Japão.

Em São Paulo - cidade muitas vezes considerada como a maior colônia de japoneses do mundo - Marco Xavier integrou a companhia Tamanduá, dirigida por Takao Kusuno, precursor do butô no Brasil. É nesse período que inicia suas investigações sobre butô e temas japoneses, participando da criação do espetáculo O Olho do Tamanduá (1995), dirigida por 
Takao Kusuno e Felícia Ogawa, juntamente com Siridiwê Xavante, José Maria Carvalho, Dorothy Lenner, Emilie Sugai, Eros Leme e Patrícia Noronha. Com projeção internacional, sendo apresentado na Alemanha, em Cuba e no Japão, e premiado no Brasil e no exterior, este espetáculo entra para história da dança paulistana, sendo muitas vezes evocado como o primeiro espetáculo brasileiro de butô ou de butô brasileiro - ainda que, do que se sabe e se comenta acerca de Kusuno, pareça nunca ter havido por parte dele uma preocupação em classificar a arte que fazia.

Até que ponto pode haver - para além do véu de um Japão fantasmal, pairando, flutuando e perturbando espíritos - um butô rarefeito que alimente, a conta gotas, o corpo faminto de artistas que sonham em outras terras? Será possível, no caso do butô, catalogar e classificar o sonho dos poetas a partir de estigmas de nacionalidade?

Por em questão essa identidade do butô é, talvez, o que torna a ideia de um butô mestiço - em si mesma uma anticlassificação - tão interessante para pensar suas derivações em culturas diferentes da de origem, já que nos permite, em vez de impor uma autoestrada a ser percorrida, navegar por outras linhas de fuga. Em suas navegações além-mar, Marco Xavier percorre, ao dançar em terras brasileiras, alemãs e peruanas, caminhos inversos - traçando também novos e próprios caminhos. É da experiência de viajar ao Japão junto ao elenco da Companhia Tamanduá, em uma homenagem póstuma ao diretor da companhia, Takao Kusuno, que ele retira motivos para compor o espetáculo Pequenos Sonhos das Folhas Vermelhas (2008).

É desse encontro de seu corpo afro-brasileiro com o corpo japonês - tendo, inclusive, dançado com o mestre Yoshito Ohno - que nasce a inspiração para essa obra que vem sendo apresentada em constantes reedições. A cada uma delas, vai incorporando novos elementos provenientes de experiências acumuladas em seus trânsitos e viagens, matizadas pela relação com sua São Paulo de origem, o que permite integrar autores e poéticas que nos pareceriam aparentemente alheias ao universo do butô:

Quando fui junto com Simone Mello na Expedição de Dança na Serra da Capivara, no Piauí, fiquei impressionado com as pinturas rupestres e comecei a me lembrar dos grafites nas ruas de São Paulo, é um depoimento das vidas periféricas gravados nas paredes, pontes, becos da cidade... e eu gosto muito da obra de Basquiat... traduz essa ancestralidade africana numa linguagem visual urbana direta, como as pinturas da Serra da Capivara; por isso usei as imagens da Serra e de Basquiat. (XAVIER, 2020).

Sobre o contexto de estreia do espetáculo, nos conta como se dá essa relação íntima com a cidade e com a obra de Takao, bem como com os artistas do núcleo em torno do qual se forma uma espécie de "arquipélago", por entre o qual pode realizar suas navegações e estabelecer parcerias:

O solo Pequenos Sonhos das Folhas Vermelhas teve a sua estreia em 2008, no Teatro Arena no projeto Arquipélago Tamanduá. Foi um convite da Cia. Livre de 
Teatro, sob direção de Cibele Forjaz, que na época realizava uma residência artística nesse espaço. A ideia era que cada integrante da Cia. fosse responsável por uma noite e todos ajudaríamos, ou participando da performance ou na produção. Neste evento convidei para dançar junto Ricardo lazzetta e Patrícia Noronha. Então foi assim durante três meses: performances que mostravam bem a diversidade do grupo e traziam o pensamento de Takao. Esse nome é Arquipélago: um conjunto de ilhas flutuando no mesmo mar; era a ideia que estava por trás. (XAVIER, 2020).

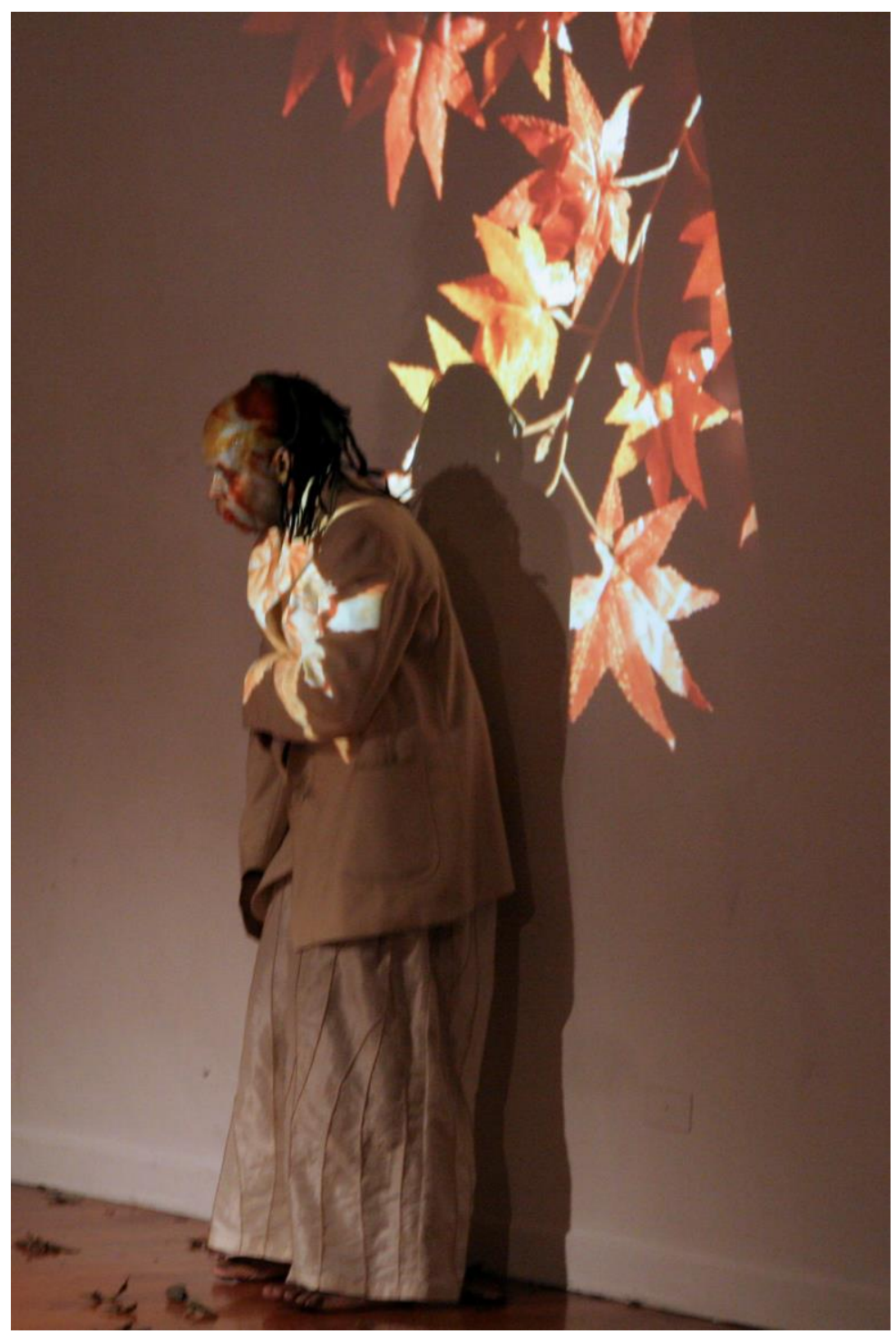

Figura 1 - Apresentação de Pequeno Sonho das Folhas Vermelhas, de Marco Xavier, em ICPNA de Miraflores. Lima, Peru, 2010. (Foto de Andrew Goodmorning).

A partir dessas noções de flutuações e derivas estabelecidas entre um corpo viajador, é possível encontrar lugar, nessa poética diaspórica ${ }^{8}$, tanto para as figuras rupestres do Piauí

\footnotetext{
${ }^{8}$ Éden Peretta (2019), na apresentação de um dossiê sobre butô, aborda o tema diásporas do corpo de carne, expressão que não apenas dá nome ao título de seu trabalho, como também ao próprio dossiê. No sentido que damos aqui, podem ser pensadas no contexto das diásporas afro-atlânticas.
} 
quanto para as pinturas do artista norte-americano Basquiat - num diálogo constante com outros artistas da cena contemporânea, favorecido pela cena urbana de uma metrópole como São Paulo, por onde passam exposições, mostras e festivais dos mais variados tipos. É justamente a partir dessa tessitura que podemos dar início ao nosso diálogo-correspondência com Marco Xavier. A dança que impulsa esta correspondência, portanto, participa do encantamento das misturas aptas a convocar o poder criativo e a reinvenção de si no contato com o outro.

\section{Cores das seivas das folhas}

Kò sí ewé, kò sí òrìsà9

Dito yorùbá

Elaboramos três questões-eixos para que Xavier pudesse expressar seu pensamento sobre a sua dança. Como investigadores do corpo, para elaborar as questões, partimos de nossos próprios interesses, criando uma estrutura que permitisse falar do corpo, da obra e da dança, movimentando-se do interior para o exterior. A primeira pergunta, elaborada pelo filósofo e performer Flávio Tonnetti, cujas pesquisas no campo dos estudos culturais se debruçam sobre as expressões do corpo contemporâneo, na interconexão entre ética, estética e política, se volta justamente para a questão do corpo afro-brasileiro, portador e gerador de afecções que expressam os conteúdos da cultura brasileira de matriz africana. $\mathrm{Na}$ formulação de caráter deleuziano, a pergunta a ser respondida por Marco, "o que pode um corpo?" (DELEUZE, 2017, p. 147), se reconfigura de modo que possa ser ampliada a partir da intersecção entre a cultura japonesa e a realidade cultural brasileira: o que pode um corpo butô afro-brasileiro?

Bem... o que pode um corpo? Encantar, chocar, desenhar, narrar... são inúmeras possibilidades. $O$ butô propõe um mergulho na própria ancestralidade, ouvir, conhecer o próprio corpo, criar, buscar maneiras diversas de comentar o tempo que se vive. Se colocar no mundo de uma maneira autônoma. Eu me encantei pela dança vendo um poeta em uma performance, ele bailava e falava seus poemas; tudo fazia sentido, seus movimentos, o poema... foi um momento em que vi a potência de uma cultura, a história não contada. (XAVIER, 2020).

Vi ali a possibilidade de um corpo não domesticado, buscando sua potência. O butô é a dança do inconformismo, da revolta, de mostrar o que está oculto, é uma dança que celebra a vida. Aí, acredito que um corpo butô afro-brasileiro rompa com estereótipos esperados, e voe. (XAVIER, 2020).

Marco Xavier apresenta um corpo que pode ser compreendido como um campo de revelação, uma geografia para o acontecimento do oculto. Há, portanto, um sentido ritual de revelar ou fazer ver o que não se via: o próprio corpo como afirmação de um modo de resistir

\footnotetext{
${ }^{9}$ A frase, muitas vezes ouvida em comunidades de terreiro ou templos de religiões afro-brasileiras, pode ser traduzida pela expressão "sem folha não tem orixá".
} 
numa cultura hostil. Essa dimensão espiritual - vinda de um candomblé também assumido como lócus de aquilombamento ${ }^{10}$ - se mostra como resistência contra uma condição social de hostilidade que se manifesta de dois modos. De um modo geral, indo contra os automatismos que bloqueiam e condicionam o corpo a comportamentos sustentados por uma noção moderna de individualidade. De um modo específico, afirmando-se como artista negro contra uma sociedade racista cuja tônica de um self encerrado sobre si mesmo e competitivo na relação com o outro busca diminuir a potência da negritude. Sua dança, portanto, não negligencia os trágicos chamados dos setores marginados. E combate, de certo modo, a perpetuação de um sistema de produtividade e lucro que não se responsabiliza pela precariedade latente à qual destina os corpos menos privilegiados - no caso específico de Xavier, um corpo negro submetido a uma exclusão que se dá num recorte racial e de classe.

A performance do poeta, assistida por Xavier, e narrada por ele como um momento importante de tomada de consciência ao longo de seu processo artístico, funciona como um disparador, como um encontro potente que atravessa sua trajetória no sentido de provocá-lo a compor seu próprio manifesto, até que possa, ele mesmo, afirmar sua arte como uma espécie de pedagogia da resistência.

O caráter disruptivo do butô, desde sua gênese japonesa, permite a um corpo afrobrasileiro não enquadrado - não domesticado, nas palavras de Xavier - que se afirme como corpo-pensamento, numa dança que permita a reflexão sobre o próprio lugar no mundo. Nesse sentido, essa forma de pensar o butô se articula com o pensamento de Hijikata sobre o lugar do corpo marginal:

O que pode um corpo? É sempre uma pergunta complexa, uma indagação que me acompanha há muito tempo, onde se pode chegar nutrindo o corpo com exercícios físicos, autoconhecimento, imagens, observar a natureza, improvisar, pensar e refletir sobre a vida, sobre as relações que permeiam a existência, a presença, estar pleno em cena. (XAVIER, 2020).

A pergunta sobre o lugar do corpo e suas possibilidades, articulada a partir de autores ocidentais, integra o repertório do butô. Mas essa pergunta, no caso japonês, se traveste de novos termos. O corpo sem órgãos de Antonin Artaud, explorado por Deleuze em suas reflexões sobre os limites do corpo, é pensado como um corpo não programado socialmente, um corpo cru, que Hijikata expressa em termos de um nikutai - corpo de carne - em oposição ao corpo social - shintai.

No caso da obra de Xavier, vemos que esse corpo de carne - nikutai - frente ao corpo social - shintai - não se deixa capturar pelas posições tradicionalmente estereotipadas que

\footnotetext{
${ }^{10} \mathrm{Na}$ acepção dada por Beatriz Nascimento, para quem há um sentido contemporâneo a partir do qual podemos pensar o quilombo como qualquer espaço territorial e cultural negro que opere como um modo de resistência relacionado a garantia de um modo de vida ancestral que se tentou destruir (NASCIMENTO, 2006).
} 
são impostas ao corpo negro. A dança de Xavier, nesse sentido, nega o corpo viril e sexualizado, como signo historicamente reservado às representações do corpo afro na cultura brasileira. Sua dança não é samba, não é axé, não é hip hop: lugares programados de afirmação de um corpo socialmente negado. O ritmo que embala seu corpo é um antirritmo não televisionado, fora dos padrões estéticos convencionais e, muitas vezes, incompreensível para não iniciados.

No desenvolvimento dessa singularidade afirmativa de si, é no corpo ancestral religioso que ele mergulha para revelar seus significados mais íntimos. Nesse ponto, sua obra se afasta da violência do ankoku butô de Hijikata para se aproximar da poética transcendente de Kazuo Ohno, dançarino da paz, cuja expressão de carne é sempre mais a da beleza do que a do terror - e para quem a beleza, como gesto, chega mesmo a ser a única resposta possível frente à horrível face da morte.

É nesse sentido profundo, até mesmo religioso, que a dança de Marco Xavier reverbera outras formas de comunicação para além da resistência, que tangenciam as perspectivas de outros inventores do butô, como Akira Kasai (1943) e Ishii Mitsutaka (1939 -2017) ${ }^{11}$. De Kasai, temos a noção de metamorfose, para quem a dança revela-se não mais como signo da brutalidade, do corpo cru, mas como significado de algo que quer vir à tona, que precisa ser revelado a partir de sua transformação (PERETTA, 2015, p. 93). Já no caso da aproximação com Mitsutaka, temos a noção de interioridade, para quem "o butô deveria expressar uma realidade profunda que só poderia ser alcançada por meio da improvisação na natureza", manifestando-se como uma dança que se dá "em campos de neve, cachoeiras e florestas" (BAIRD, 2019, p. 4).

Essa metamorfose de um corpo duplo, em conexão com uma interioridade revelada pela natureza, nos coloca diretamente em contato com valores que, na obra de Marco Xavier, encontram sua tradução através do candomblé - num transe performado por um corpo improvisador em conexão com elementos da natureza.

Os temas da natureza e de seus ciclos, tão caros à cultura japonesa, comuns à tradição religiosa xintoísta e à literatura budista - manifesta pela forma poética dos koans e haikais são incorporados por Xavier e transmutados em uma nova gramática cultural. No tombar das momiji ${ }^{12}$, na cena outonal das folhas que caem, ele encontra analogias com o culto aos orixás do candomblé brasileiro, que expressam as forças da natureza e a conexão com outras

\footnotetext{
11 Ambos os bailarinos participaram do elenco criado por Hijikata em 1961. Esta formação, que contava ademais com Kazuo Ohno e seu filho Yoshito Ohno, durou até 1966. Cf. Wikidança.net [s/d].

${ }^{12}$ A contemplação das folhas momiji no outono está ligada a um profundo senso estético japonês, que revela um tipo de conexão com a natureza muitas vezes expresso nos gêneros poéticos tradicionais dos koans e haikais, aqui mencionados. Mas, além disso, a presença das momiji se dá também na linguagem visual das tatuagens japonesas (SHIMADA, 2020), numa dimensão corporal que se articula enormemente com a dança butô, sobretudo quando pensada na perspectiva dos corpos marginais.
} 
formas de ser. Em Pequenos Sonhos das Folhas Vermelhas ele vai buscar na figura do orixá Ossaim uma possibilidade de tradução e transposição dessa mesma poética.

Considerado o pai das folhas, Ossaim é quem dá permissão para o uso das plantas na liturgia do candomblé, e é pela sua presença que a energia curativa das folhas se distribui entre os orixás. É por isso que a sua presença é tão importante no contexto dessa ritualística, já que é esse orixá quem irá garantir a circulação do axé das seivas e folhas, invocando o próprio movimento da vida (ODÉ KILEUY; VERA DE OXAGUIÃ, 2018).

O que me despertou, ou me inspirou, foi a chegada do outono no Japão, as folhas de momiji ficam vermelhas, o chão fica coberto de folhas vermelhas, é uma paisagem muito bela; comecei a pensar no outono do corpo, se desvencilhando do que já não te serve mais, como uma árvore que solta folhas no outono e - ao mesmo tempo - me veio à memória o mito de Ossaim, o orixá das folhas. Estes foram os elementos ou ideias, imagens, intenções, que nortearam a criação. As folhas sonham ao sabor do vento. O chão coberto de folhas é puro encanto. (XAVIER, 2020).

Uma das folhas mais marcantes usadas no espetáculo é justamente a de uma Costela de Adão, espécie de arácea consagrada à lemanjá, a grande mãe, responsável pelo nascimento e pelo acolhimento, regente de todas as cabeças, fluxo das águas que dá vida a todos os seres. A folha, de grande formato, invoca a criação da vida interligando mitologias africanas e cristãs, já que a folha escolhida, que representa a orixá mãe, tem em nossa cultura o nome do primeiro humano da narrativa cristã - Adão. É esse sentido mestiço - e sincrético - da criação que passa a ser invocado na poética corporal de Xavier, onde as diferenças encontram um lugar de diálogo, no qual a dança da resistência e da morte passa a ser considerada uma dança da criação e da vida.

As ideias vão se ampliando, se verticalizando: não se trata mais só de um solo baseado no mito de Ossaim ou de outono de um corpo, mas também de uma luta para se libertar de códigos que foram impostos, de se conectar com a ancestralidade, de mostrar também o quanto somos frágeis perante a vida. (XAVIER, 2020).

\section{Cores dos sonhos do corpo}

Eu não penso em arte quando estou trabalhando. Eu tento pensar sobre a vida. Jean-Michel Basquiat

A segunda questão, acerca dos elementos que compõem a cena, foi lançada por Sandra Corradini, performer, coreógrafa e pesquisadora de dramaturgia no campo da dança, com especial interesse no trânsito Oriente-Ocidente sob a perspectiva da cena expandida. A pesquisadora tende a olhar o trabalho de Marco Xavier, em especial a dramaturgia corporal 
configurada em Pequenos Sonhos das Folhas Vermelhas, como manifestação de uma busca esmiuçada e depurada no corpo, ancorada em um projeto ambicioso e não menos ousado de reinvenção de si e do mundo.

Nesse trabalho, o corpo é lugar onde a potência dos sonhos ganha importância vital, movido pelo desejo de trilhar caminhos não habituais e de configurar novos modos de existência. Pequenos Sonhos das Folhas Vermelhas, ao qual Xavier se refere quase sempre usando apenas o termo Folhas, mostra como as relações arte-vida são renovadas e assumem novos contornos em meio a uma trama complexa de forças invisíveis, ganhando tensões e intensidades concretas, materializadas no corpo, dançadas para além dos simbolismos e das representações tradicionalmente convencionados em contextos religiosos e artísticos - o que se dá tanto pelo uso de recursos tecnológicos de vídeo, que criam camadas de significado por meio de projeções sobre a cena e o corpo do bailarino, quanto pelos elementos acionados a partir do figurino, que reforçam a um só tempo a referência ao candomblé e ao universo simbólico do butô japonês. Trata-se de um trabalho sincrético cujo histórico carrega questões que vêm sendo repensadas e reformuladas ao longo dos seus 12 anos de existência, desde a sua estreia oficial em 2008. Nessa trama multicultural, como se coloca o corpo negro em cena?

No evento Tokyogaqui, no Sesc Paulista, com Tamanduás Agora em Bando, me aprofundei mais na questão corporal, explorando mais ideias de movimento, e comecei a pensar que esse corpo também expressava ou também fazia um paralelo com as ideias de Frantz Fanon, de Abdias do Nascimento, e de muitos outros escritores que discutiam o racismo estrutural e suas consequências, o trabalho vai se transformando, ficando viçoso como árvore. (XAVIER, 2020).

A menção a Abdias do Nascimento, que já na década de 1970 tratava da problemática do genocídio do negro brasileiro (NASCIMENTO, 1978) e da importância de criar espaços de maior representatividade para pessoas negras nos mais diversos campos da cultura ${ }^{13}$, nos dá o testemunho inequívoco de como Xavier pensa a presença performativa do corpo negro em cena como uma afirmação política e identitária.

A menção a Frantz Fanon, cuja obra mais conhecida é Pele negra, máscaras brancas, sugere apontar para o cuidado em não negar ou diminuir a própria negritude como marca de expressão social. Uma articulação com Fanon pode ser feita, ainda, para pensarmos sobre os usos performáticos que Xavier faz de máscaras africanas em diversas de suas coreografias, como se as utilizasse para afirmar uma "pele negra com máscaras negras", usando a máscara não como forma de encobrir, mas, novamente, como forma de revelar se opondo ao caráter embranquecedor para afirmar a cultura de matriz africana como componente ancestral importante na composição da cultura brasileira.

\footnotetext{
13 Abdias do Nascimento é um dos maiores expoentes do movimento negro brasileiro. Ator, dramaturgo e professor, foi o fundador do Teatro Experimental do Negro (TEN), do Museu da Arte Negra (MAN) e do Instituto de Pesquisas e Estudos Afro-Brasileiros (IPEAFRO).
} 
No conjunto coreográfico do espetáculo Folhas, a presença performativa do corpo negro vai se apresentando na cena a partir de uma plasticidade corpórea constituída entre o pulso e o impulso, e permeada por pensamentos nipônicos e afro-brasileiros amalgamados em uma mistura sensível de arte com religiosidade. Para Xavier, Folhas é uma "luta para se libertar de códigos impostos e se conectar com a ancestralidade" (2020) na busca por evidenciar a fragilidade inerente à vida humana, acirrada frente à normalização da violência pela sociedade contemporânea.

De partida, Xavier propõe pensar a metáfora poética do outono do corpo a partir da imagem das folhas de momiji, guardadas em sua memória, desprendendo-se das árvores no outono japonês e colorindo o chão com um vermelho intenso por um período de aproximadamente um mês. Para ele, em sua etapa outonal, o corpo pode ser visto como uma árvore que solta suas folhas, desvencilhando-se daquilo que não lhe serve mais.

Uma análise breve dos processos da vida vegetal permite compreender tal fenômeno como uma estratégia que garante à árvore sobreviver ao inverno, modificando suas características para reduzir ao máximo seu gasto energético e utilizá-lo para seu próprio aquecimento. Mais que uma solução fisiológica do organismo em resposta aos estímulos do ambiente, trata-se de um comportamento indicativo da sua eficiência adaptativa, figurado pelo processo de retorno ao que lhe é essencial para manutenção e continuidade da vida, sinalizando sua interação com o meio, cujos elementos lhe mostram o momento propício para que esse processo transformador ocorra.

A metáfora do outono no corpo produz sentidos figurados nesta dança de Marco Xavier, sugerindo ideias que extrapolam os limites do biológico, incorporando as dimensões histórica, política e cultural na discussão sobre o corpo negro e a afrodescendência não apenas no butô no Brasil, mas também ampliando-a para além dos muros da dança e das artes performativas no país e no exterior, como indicam as menções à Abdias do Nascimento e Frantz Fanon ou à discussão que propomos sobre necropolítica a partir de Achille Mbembe ou conforme retomada por Silvio de Almeida.

Em termos estéticos, na obra de Xavier, o silêncio e a escuridão são elementos introdutórios que induzem o espectador a um mergulho introspectivo na obra, de onde emerge uma sonoridade composta de pequenos objetos que caem acompanhados de crepitações agudas, produzidas, respectivamente, pela queda e pelo o estalar das folhas secas no espaço-tempo da cena. Trata-se de uma paisagem sonora sugestiva de uma condição préexistente à presença do corpo no espaço cênico, cujas ações vão sendo delineadas à medida que a performance avança e a intensidade da luz aumenta, delimitando gradativamente 0 espaço poético da dança.

Já na penumbra, é possível identificar a ação do corpo no espaço, engendrada pela retirada de folhas dos bolsos do paletó do performer. As folhas, que vão ao chão, após se 
soltarem de suas mãos como chuvas de si, desenham movimentos que partem do centro do corpo e se abrem como fonte no espaço circundante. O estalar das folhas sob os pés do performer, ao serem pisadas, inteira o sentido etimológico de sua dança, denotando a presença dos dois núcleos do butô, representados pelos ideogramas japoneses "bu", que designa mãos, pairar, ou simplesmente dançar, e "tô", que significa golpear a terra ou pisar (KATZ, 1988). Juntos, esses ideogramas deslindam o constante jogo de luz e sombras presente no corpo que dança para além do dualismo que frequentemente demarca extremos estáticos e rígidos. Aqui, uma perspectiva distinta se desenha, indicando tensões e variações cinéticas e tonais infinitas entre polaridades extremas, possibilitando a diversidade de leituras do mundo e da vida.

Em Folhas, o figurino é mais que um simples adereço: é agente criador de efeitos. Repositório de folhas ocultas, seu paletó branco contrasta com a cor escura de sua pele, assim como o fosco do tecido realça o brilho de seu rosto suado. Sobre sua figura, vai se refletindo uma projeção de vídeo, que o transpassa em direção ao fundo da cena. Sua vestimenta recebe, então, essas paisagens projetadas, ao mesmo tempo em que projeta uma sombra sobre o pano de fundo da cena que, por sua vez, passa a funcionar não mais como um delimitador do espaço cênico, mas como uma grande tela - uma espécie de janela que nos abre para outras paisagens. Cumpre lembrar que, no candomblé, o branco é a cor da vestimenta ritual - o mesmo branco que, adotado no butô de Kazuo Ohno, remete, na cultura japonesa, à noção de morte ou de inverno.

Ao som da Sonata $n .914$ em D Sustenido Menor, Op. 27, n. 2, de Ludwig Van Beethoven ${ }^{14}$, o corpo do dançarino se desmembra em três: ora como sombra movente, em um recorte que marca a tela ao fundo, ora como célula orgânica composta de pequenos pedaços animados de folhas, destacados em seu paletó pela projeção de vídeo, ora como corpo presente, real e concreto, movendo-se em um misto de dor, choro, luto e melancolia, construído aos mínimos detalhes de tensão e relaxamento manifestos em sua pele. Um giro crescente e ascendente impõe-lhe um estado de desequilíbrio irreversível, colocando-o em outra dimensão. As folhas, que pouco a pouco não mais lhe pertencem, agora tingem o chão e criam rastros nas suas idas e voltas cambaleantes, entre quedas e suspensão.

As ideias e as imagens que expandem este solo poético emergem de um processo dramatúrgico que se fez no curso do tempo, preocupado com o corpo em seu aspecto multidimensional, enfocado não apenas do ponto de vista físico, mas também mental e espiritual. Sua poética outonal, enlaçando o mito de Ossaim, permite olhar a cena sob uma perspectiva ritualística, expressa no cuidado do preparo do corpo e do espaço, implicado à sua maneira de ver e de agir no mundo. Conforme explica o performer:

\footnotetext{
${ }_{14}$ Peça musical composta em 1801 e que posteriormente veio a ser conhecida universalmente como Sonata ao Luar. Trata-se de uma peça consagrada no butô, dançada por Kazuo Ohno, a quem o artista presta reverência.
} 


\begin{abstract}
O ritual, de uma certa maneira, está inserido na minha maneira de ver o mundo, de agir; não é possível, a meu ver, reproduzir um ritual no palco, mas posso ter o cuidado ritualístico de preparar o corpo, o espaço. Quando falo de preparar o corpo não é só o trabalho físico, muscular, mas tratar de tudo como se trata uma flor. E ouvir o próprio corpo: o que ele tem a dizer sobre determinado tema que foi escolhido, como o corpo gera e organiza a informação que ele traz, como seu treino se transforma em linguagem. (XAVIER, 2020).
\end{abstract}

Além de dançarino e ator, Xavier também é músico e compositor, de modo que a presença de composições musicais próprias em seus trabalhos de dança é bastante frequente. Em Pequenos Sonhos das Folhas Vermelhas, além de dançar, Xavier faz do corpo seu instrumento percussivo, em especial, sua cabeça nua, onde inicia um toque ao orixá da mata e das folhas, detentor do segredo das plantas. Posicionado no centro da cena, bravo, valente e selvagem, o dançarino evoca um diálogo entre dança e música, conectando o visível ao invisível, o si mesmo com a sua ancestralidade transcendente. Um pequeno tremor em sua cabeça intensifica-se gradativamente, incorporando tronco, braços e pernas, com ondulações, quebras e giros característicos de sua dança, instaurando mudanças expressivas em seu corpo, sobretudo, fisionômicas, sobre as quais se fecha o foco central, oferecendo ao público essa nova máscara, configurada em seu rosto humano, com olhos, boca, testa e bochechas grandes, e vocalizações incognoscíveis, a qual permanece como uma imagem etérea para além da luz que a funda.

\title{
VI. Cores da carne do encontro
}

Azul, amarelo, verde, verdinho, marrom Percebam que a alma não tem cor

André Abujamra

A terceira e última pergunta é projetada por Simone Mello, dançarina e pesquisadora do butô em suas flutuações na América Latina. Como colaboradora de Xavier em diversos projetos entre Brasil e Peru, teve inúmeras oportunidades de contemplar seu trabalho. Além disso, Marco Xavier ofereceu uma série de contribuições para a dissertação de mestrado de Mello (2013) sobre o legado de Takao Kusuno e a Cia. Tamanduá. Essa caminhada conjunta, de indagações e afetos, marca a construção desse ensaio em seu método.

Recordemos que a palavra método é normalmente usada para referir-se a um certo caminho que nos permita chegar a um fim. Méthodos, em sua acepção grega, é palavra composta por metas, deslocamentos e atravessamentos que se implementam durante a trajetória. Nessa rama de caminhos bifurcantes, tendo como alvo cartografar metáforas, passamos a buscar figuras de linguagem - expressas por palavras e imagens - a partir das quais possamos tecer analogias que sinalizam as qualidades do corpo que dança - mas não de qualquer dança; e sim daquelas metabolizadas num corpo afro-butô. 
Tais figuras de linguagem encarnam, como denúncia, o trabalho reiterado dos corpos que Xavier projeta sobre o cenário artístico atual. São formulações próprias que orientam o conjunto de procedimentos e estados que aqui tratamos como metáforas-testemunhos: imagens que expressam, por meio de recursos estilísticos, as vivências do próprio corpo do autor - e dos autores implicados nesse diálogo - expostos a partir de conteúdos simbólicos, que correspondem a um universo de nossas singularidades enquanto pesquisadores-artistas, dando prova, confirmação e demonstração de uma experiência que se conhece enquanto se vive - atravessados por processos da mestiçagem cultural.

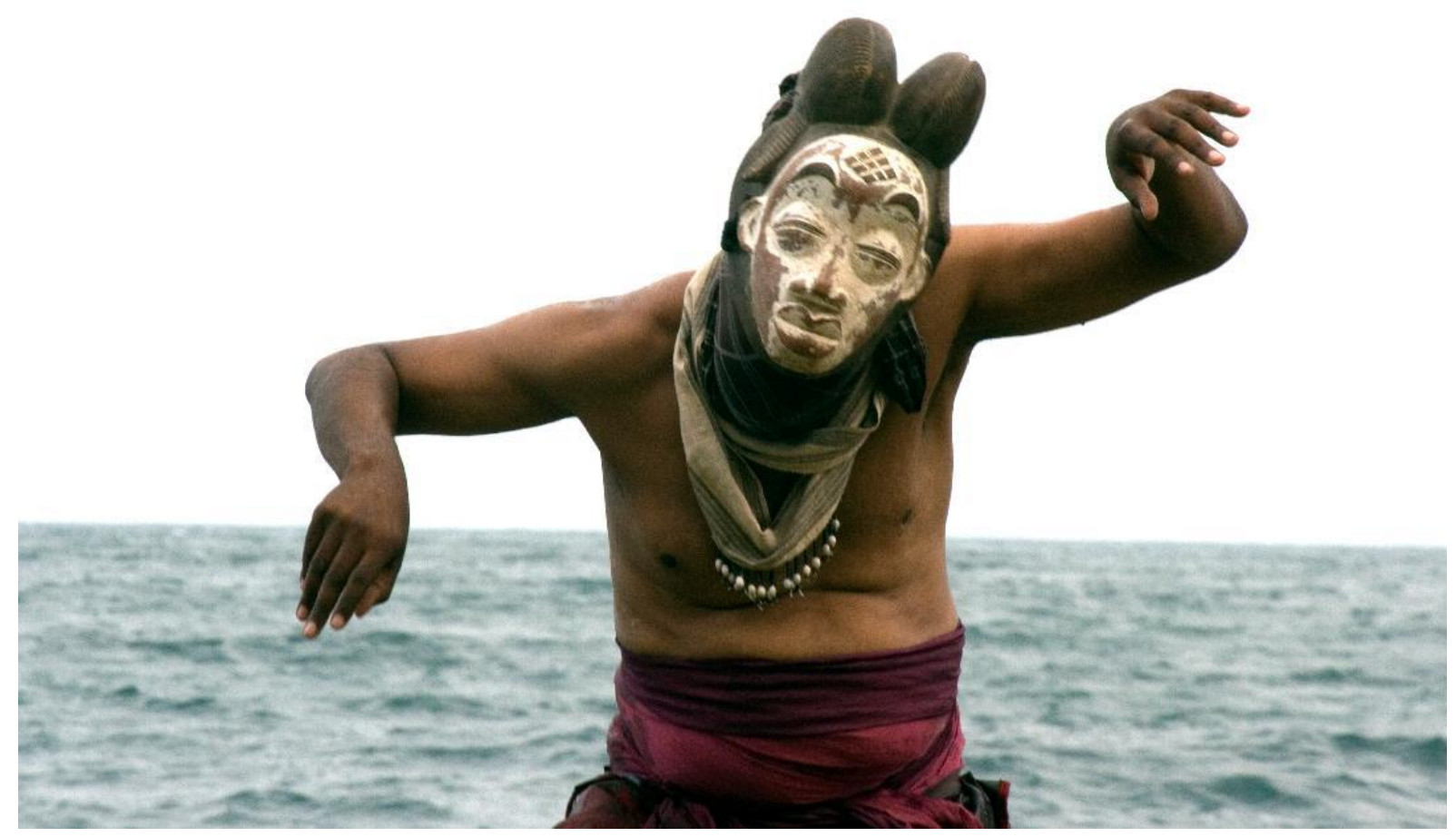

Figura 2 - Flutuações do Butoh, ensaio fotográfico com Marco Xavier. Rio Vermelho, Salvador, Bahia, 2011. (Foto de Paulo Cesar Lima).

Nessa perspectiva é que Mello pergunta a Xavier: quais seriam as metáforas-dançarinas que podemos destacar nesse butô afro-brasileiro?

Dançar é uma arte tão difícil e efêmera, aqui agora. Há vezes que fico olhando o vento e os seus efeitos. É muito inspirador, tudo vai mudando, mesmo a rotina imposta pela quarentena (Covid-19) vai nos mostrando algo do passado ou do presente. Um sabiá ficou me olhando outro dia enquanto eu improvisava pensando em nuvens; e só foi embora, quando parei. (XAVIER, 2020). 


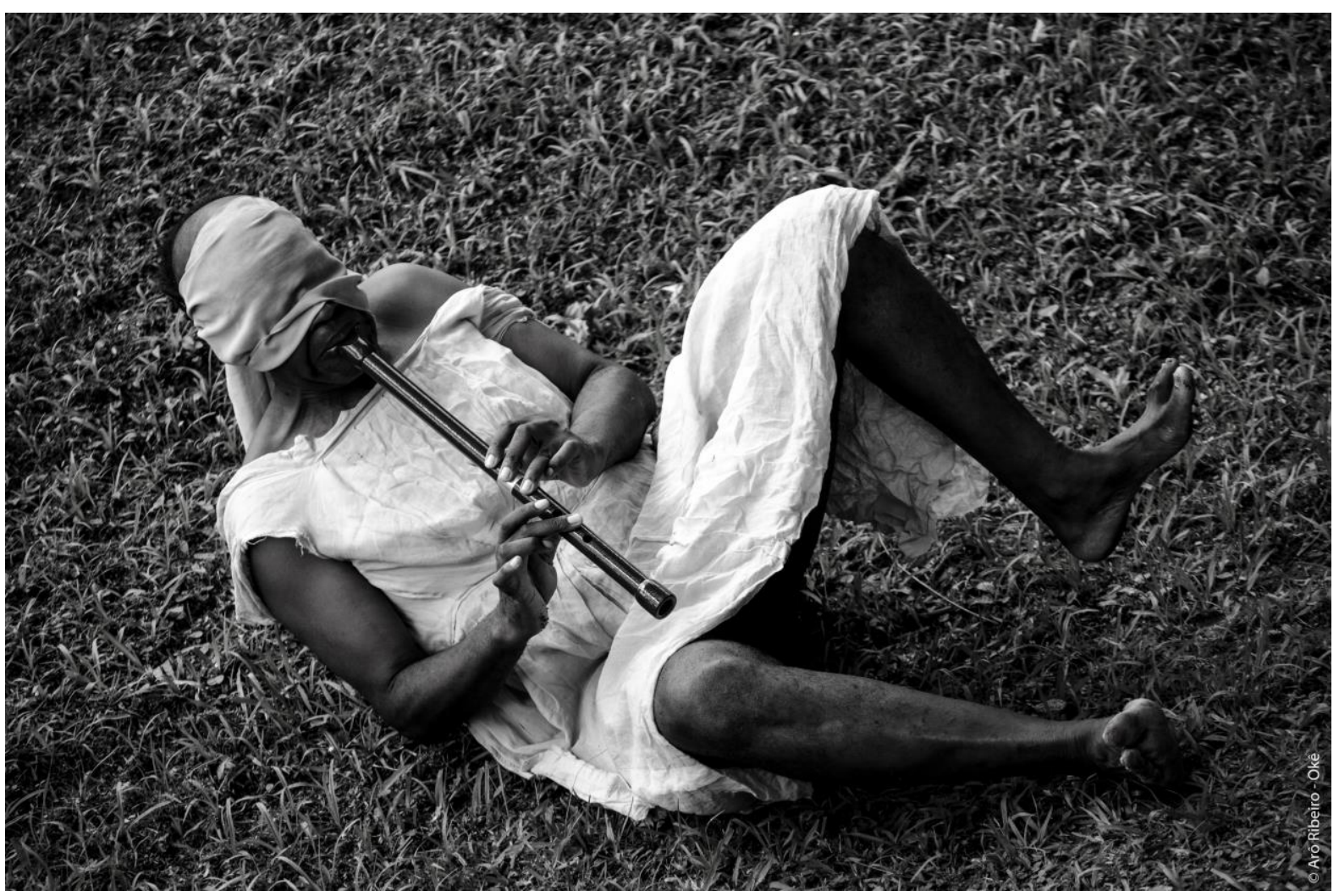

Figura 3 - Marco Xavier. Centro Cultural Jabaquara, São Paulo, 2014. (Foto de Arô Ribeiro).

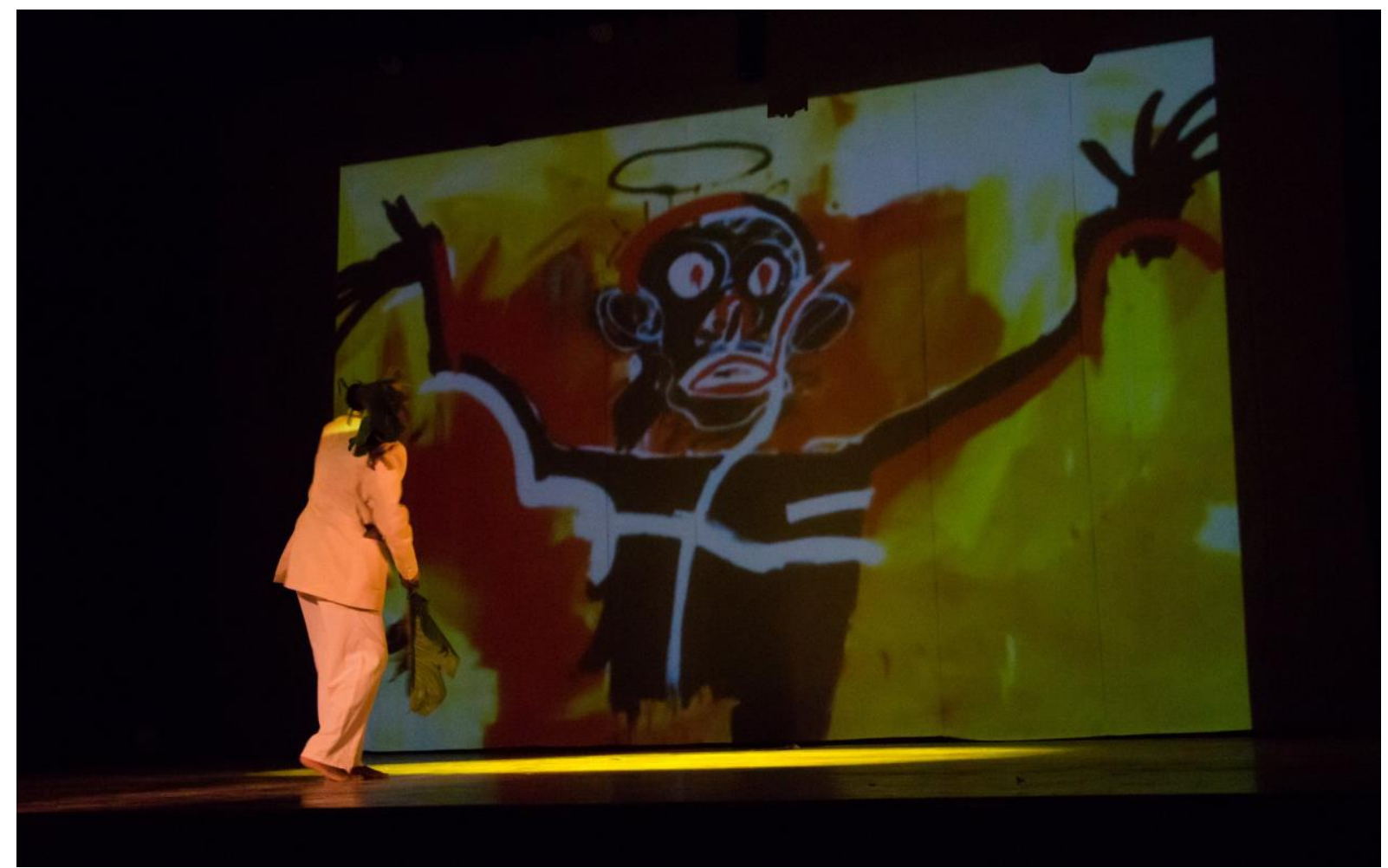

Figura 4 - Apresentação de Pequeno Sonho das Folhas Vermelhas, de Marco Xavier. Teatro Municipal de Cusco, Peru, 2016. (Foto de Ricardo Guevara). 
Todo aprendizado deve considerar que as sementes ao vento necessitam de um solo fértil para seu crescimento. Os corpos também, para florescer em poesia. Pelas especificidades históricas e políticas, fazer arte no Brasil poderá parecer um esforço absurdo: um lançamento de sementes em terras duras, retomando a parábola cristã do semeador, como elemento que também compõe a diversidade do imaginário brasileiro ${ }^{15}$.

Assim como no contexto estéril do pós-guerra que deflagrou o butô, nos encontramos, como terra e povo, exauridos e explorados em uma dimensão catastrófica, tendo o corpo como agente das rebeliões contra tudo que confina a criatividade, a vitalidade e a fertilidade - mais uma vez, o deserto de Krenak nos acode como metáfora. Mas, finalmente, neste continental corpo de terra que é o Brasil, a informação segue reciclando-se e chega para se misturar. Da terra dura do Japão de Hijikata, que se fez nova vida a partir da lama, o butô, que vem sendo plantado em diferentes solos, abriga distintas variantes e convoca fios de outras memórias-culturas, como elaboração de uma matéria resistente, que vai buscar fincar suas raízes nas profundezas dos solos mais duros. É o caso de Xavier, que investe seu corpo cênico nas fontes africanas de seus antepassados.

Quando eu comecei a dançar era uma afirmação política. Queria mostrar a dança dos meus ancestrais, a diversidade, a beleza e me afirmar como homem negro. Foi nesse momento também que começou a luta pela inclusão da história da África no currículo escolar, que mais tarde veio a ser lei. E lutamos até o fim do racismo estrutural. À medida que fui descobrindo a história do negro em África e todo o movimento diaspórico, fui percebendo que a minha cultura era mais próxima dos orientais do que dos ocidentais. Sacralidade da vida, respeito aos mais velhos, a relação com a natureza... Hoje danço como uma coluna de fumaça que baila na terra, que exibe uma sensualidade poderosa, que evoca a vida e sua potência. (XAVIER, 2020).

A imagem da coluna de fumaça compõe um conjunto de metáforas aéreas exploradas por Xavier. Durante os ensaios com o coletivo que dirige, Paisagens Flutuantes, ou nas aulas que ministra, Marco costuma sugerir que cada um "seja folha que se move ao vento". Além do elemento ar, também o elemento água e o elemento terra aparecem em sua pedagogia. Em seus laboratórios-treinamentos, como mestre de butô, é muito comum surgir o tema do atravessamento ou da deriva por meio da proposição de caminhadas: caminhada do boi, caminhada das flores, caminhada do coração. "Caminhem!" para encontrar formas próprias de seguir caminhando, a partir do encontro com o outro e consigo mesmo.

Em alguns casos, sugere caminhar na lama primordial ${ }^{16}$, deslizando pés e fincando 0 peso do corpo no pasto, como boi. Ou imaginar duas linhas esticadas em direções opostas,

\footnotetext{
${ }^{15}$ No contexto dessas aproximações, é importante lembrar que elementos cristãos compõem o universo ritual das religiões afro-brasileiras, sobretudo, mas não somente, nas vertentes da umbanda. No contexto do butô, vale lembrar, ainda, que Kazuo Ohno converteu-se ao cristianismo em 1930, professando uma fé cuja influência é perceptível em sua poética artística. Cf. Yokoyama (2018) e Ponzio (1997).

${ }^{16}$ A lama primordial está ligada, no candomblé, à figura de Nanã, orixá feminina que forneceu à Oxalá o material a partir do qual seriam criados os seres humanos (PRANDI, 2003).
} 
que se conectam com pontos extremos no espaço, propondo ao caminhante que busque não afrouxar as linhas durante as ininterruptas horas da travessia - uma hora, duas horas, três horas - para que o corpo se estenda no tempo. Corpos como relógios de Salvador Dalí, se desintegrando, dissolvendo, esvaziando a cabeça de pensamentos, esquecendo-nos de nós mesmos e da caminhada. Esse "método" busca a presença do corpo pelo esgotamento de si mesmo, em exercícios conceitualmente ancorados em metáforas. A própria exaustão aparece como imagem poética. E o trabalho como convicção.

\begin{abstract}
Me recordo quando tive que dançar no evento Vestígios do Butoh, no Sesc Consolação, evento que foi seguido de uma confraternização com todos os artistas convidados à casa da Sra. Tomie Ohtake. Foi aberto um barril de saquê, fizemos um brinde e lá estavam Yoshito Ohno, Akira Kasai, Mitsuru Sasaki, Ismael Ivo, Koffi Kôkô e vários outros artistas que no momento não lembro os nomes, mas todos falaram: vamos ver o espetáculo amanhã. Íamos dançar o Olho do Tamanduá no dia seguinte. Fui dormir apavorado, toda aquela constelação de artistas da dança estaria lá, demorei para dormir. No dia seguinte acordei e pensei que o máximo que poderia acontecer era eles não gostarem, e que isso não tinha a ver comigo. Era um trabalho que ajudei a construir, era a dança que eu queria fazer, eu estudei, me dediquei e foi assim que entrei no palco fortalecido, dançando com a memória de Takao e seguro da minha dança. Foi uma noite excepcional e os artistas japoneses vieram agradecer depois. (XAVIER, 2020).
\end{abstract}

Entre as fragilidades e certezas de um artista às vésperas de uma apresentação importante, o treinamento aparece como base para que o trabalho seja desempenhado de forma sólida e consistente. É essa experiência que Xavier leva para sua prática como educador no campo da dança. Quando alguém no grupo de trabalho reclama do cansaço ou questiona os estados físico-mentais que experimenta durante os longos ciclos de seus treinamentos, ele responde:

Seja como um cisne! Apesar de seu peso, os cisnes voam muito bem. Suas asas levantam um peso quatro vezes maior em comparação com as gaivotas. $O$ cisne trabalha forte, com suas patas dentro da água; mas, por cima dela, flutua docemente, desliza elegante, de modo que ninguém percebe seu esforço. (XAVIER, 2020).

Não sabemos ao certo se a metáfora do cisne usada por Xavier era também um mote usado por Takao, imagem talvez emprestada pela convivência, a grande mãe dos sincretismos e das misturas. No fluxo do pensamento mestiço (SERRES, 1993), dançar é uma navegação. O método do bailarino-diretor, seu caminhar - não segue uma linha reta. $O$ dançarino, com seu corpo, se lança ao mar de possibilidades. Durante o trabalho físico junto ao coletivo Paisagens Flutuantes, Xavier muitas vezes relata as memórias vividas na Companhia Tamanduá como um trabalho de rememoração. É Michel Serres, filósofomarinheiro, quem inspira um modo de pensar o corpo que dança, flutuando, nas ondas da experimentação: 
Voilà! Ora, no mar não existem auto-estradas... Quer dizer que se você quer ir um pouco mais à esquerda ou um pouco mais à direita, você tem muito mais liberdade do que numa auto-estrada. A auto-estrada é direcional. Não, o mar. E, portanto, a metáfora da navegação me parece mais justa, porque há flutuação, há tempestade, há turbulências, há coisas que não são assim tão direcionais; no fundo, é a diferença que há entre o sólido e o líquido. A metáfora da auto-estrada é uma metáfora sólida e a metáfora da navegação é uma metáfora líquida. Ora, o sólido é um cristal ordenado, enquanto o líquido é um conjunto de moléculas desordenadas. Voilà! (SERRES, 2000, p. 137).

A metáfora da navegação nos parece adequada para pensar o butô penetrando em novas terras. Investigar o butô nas margens de Xavier nos permite percorrer o "caminho das pedras" que o artista trava, em busca de se afirmar como alguém que não pode seguir senão pelo caminho a ser aberto por si mesmo. O próprio corpo como pedra de apoio, a partir do qual se pode observar tudo o que nele é preenchimento e tudo o que nele é serpentear invisível, de um vazio incapturável pelos discursos. No caminho do butô que flutua em nossas terras - nas dinâmicas de diásporas, migrações, êxodos e exílios - o percurso requer ser reinventado a cada etapa.

O que é essa dança de contornos flutuando no branco mundo espiritual? O corpo não tem forma definida. O mundo preto, o segredo, o que está oculto, as raízes. Eu vejo tudo isso no butô. (XAVIER, 2020)

Atentos ao que ainda podemos fazer juntos, enquanto artistas-educadores-pensadores, meditando coletivamente sobre o corpo, que se sente a um passo do colapso, e nos misturando uns aos outros entre corpos-pensamentos, Xavier conta-nos um pouco mais sobre seu caminhar-dançarino e nos convida a acompanhar seus passos nessa caminhadanavegação, onde dançar é ter liberdades que perturbam. Conta-nos o que quiser:

Com o coletivo Paisagem Flutuantes, vamos participar do Laboratório de Trocas do CRD (Centro de Referência da Dança da Cidade de São Paulo). A participação vai ser on-line, e pensei em um vídeo: um homem tocando piano e uma mulher em cima dançando, com uma projeção de nuvens. Uma metáfora do tempo, que passa entre nós, confinados, transbordando, sonhando, recordando e inventando novos espaços. Mas a dançarina achou muito difícil criar algo assim. E pensei: fique lá e dance! E ela continuou; mas os gestos... eu precisaria estudar os gestos... na altura do projetor... e a roupa e o significado dessa imagem, e continuou e blá, blá, blá. Mas eu me pergunto, e a dança? É legal conceituar, poder falar de uma maneira clara sobre o trabalho, mas a meu ver é o trabalho do corpo, da experimentação, que vai mostrando os caminhos, tecendo o discurso poético. (XAVIER, 2020)

Na poética de Marco Xavier, a mulher que dança sobre o piano, surge, então, como metáfora da condição do corpo-nuvem, uma imagem fugidia e fluida, dotada de radicalidade gasosa, sempre em vias de escapar. O corpo que ainda não dança sobre o piano, é um corpo em dificuldade de lançar-se, de dançar-se, porque se perde no embate racional, em meio à nebulosa tarefa de almejar estar à altura de um corpo de mulher em perfeito virtuosismo: bem- 
apessoada, bem-apresentada, bem-posta, bem-feita17. Em sua experiência, Xavier sabe que, para que possa surgir como corpo rebelde, o exercício da mulher-nuvem exige o desprendimento, a metáfora airosa, que implica em dançar imersa no nevoeiro. Uma dança nuvem traz consigo o deslocamento do corpo em transe: a dança como rebelião, o corpo como o grito do recém-nascido. A dança como dor manifesta: corpo-nuvem, nutrido de ideias, sensações, percepções e lutas, que se formam, passam e desaparecem, mas, antes, se projetam ao mundo na poesia de Xavier.

Tem uma galera bem jovem no CRD da periferia, muito potente. Alguns com um discurso bem articulado e lutam através da dança, do Hip Hop, Vogue e muitas outras danças. São corpos negros periféricos que dizem: estamos aqui, temos a nossa cultura. Ou como falou Conceição Evaristo: "eles querem nos matar, mas esqueceram de combinar". Eu sinto falta de um mergulho mais profundo na pesquisa corporal desses grupos, claro que falo de alguns que vi recentemente, mas São Paulo tem muitos grupos. (XAVIER, 2020).

Entre autores-interlocutores e leitores sempre tão diversos, a dança convoca esforços. E nesta diversidade de corpos, danças e fusões, cabe recorrer à Deleuze sobre a questão do aprendizado:

Nada aprendemos com aquele que nos diz: faça como eu. Nossos únicos mestres são aqueles que nos dizem "faça comigo" e que, em vez de nos propor gestos a serem reproduzidos, sabem emitir signos a serem desenvolvidos no heterogêneo. (DELEUZE, 2006, p. 31).

A fala de Xavier aponta para esse sentido de fazer junto numa cidade tão diversa como São Paulo, em si mesma celeiro do hibridismo, mas, por vezes, carente de mestres. A cidade apontada como lócus de corpos diversos e potentes, deu a ele seu mestre. Xavier nos conta sobre Takao Kusuno:

Takao foi meu mestre. No nosso primeiro encontro, ele me pediu que mostrasse as danças que eu trazia no corpo. Ele sempre trabalhava com o que cada dançarino tinha a oferecer. Sempre nos nutrindo com imagens, enquanto preparava o almoço, ou passeando com o cachorro; era sua maneira de compartilhar ideias. Às vezes ficávamos muito tempo em silêncio; dessa maneira íamos absorvendo e transformando nossas danças. (XAVIER, 2020).

$\mathrm{Na}$ nau em que se embarcam corpos de vivos e mortos, a dança que se dança em silêncio dá espaço para que possamos reverenciar mestres de todas as ordens, tempos e culturas. Dançar não é mais mover-se na perseguição dos sons, mas observar os ritmos dos silêncios. Acolhidos os silêncios - as diferenças - e os desafios, podemos passar a dançar

\footnotetext{
${ }^{17}$ No trabalho desenvolvido por Xavier com performers mulheres, podemos perceber que à problemática do corpo racializado somam-se questões em torno do corpo generificado. E possível discutir, em sua obra, de que forma o "corpo rebelde feminino" retoma uma diversidade de corporalidades arquetípicas do ser feminino presentes nas religiões brasileiras de matriz africana.
} 
juntos nesse círculo do eterno aprender, como num enorme xirê, esse momento ritualístico que no candomblé representa a festa como acontecimento de renovação e circulação do axé.

Tanto o xirê poderia ser visto como um momento de prática do butô - em que os corpos encarnam um evento transformador, atemporal, para viver um devir natureza da vida através da dança - quanto o butô poderia ser compreendido como um xirê, momento de encontro de entidades de diferentes tempos e espaços, uma sagração multicultural em que o encontro faz acontecer uma festa do corpo e da renovação da existência - reforçando as metáforas dos fluxos, das nuvens e das metamorfoses. Na linguagem do povo de santo, o xirê é justamente um momento em suspensão, ao longo do qual canta-se para os orixás, louvando-os e homenageando-os, com a culminância de um momento mágico em que, através dos toques dos tambores, os tempos se dilatam. É a hora de virar no santo.

Xavier em seu corpo outonal, Homem-Galinha D'Angola ${ }^{18}$, que dança e prepara 0 terreiro com os pés, merece a referência de ter sua obra conversada, difundida e pensada como marco da dança brasileira. Afrontando o instante com uma gestualidade que conecta culturas, dá testemunho de que a terra do dançarino é seu corpo misturado de cores. Dançamos ao redor do bailarino-nuvem, entre memórias e histórias que semeiam a terraterreiro: com a cabeça raspada, baila o mestre de uma cerimônia pública, que começa com uma fila e vai se estendendo do mais novo ao mais velho. Essa fila se torna um círculo, unindo o passado e o futuro. Ao dançar, Xavier permite que o Orixá possa manifestar luzes e sombras. Dança o corpo dilatado por suas intensidades: dancemos todos. Ewé Ó!

\section{Referências}

ABEL, Thiago; ALEIXO, Daniel. Sol e Lama: corpo e morte em Tatsumi Hijikata e Yukio Mishima a partir de Cores Proibidas. Arte da Cena, v. 6, n. 2, ago./dez. 2020. Disponível em: https://www.revistas.ufg.br/artce/article/view/65523. Acesso em: 09/09/2021.

ALISHINA, Juju. Butoh Dance Training. Londres: Singing Dragon, 2015.

ALMEIDA, Silvio Luiz de. Racismo estrutural. São Paulo: Pólen, 2019.

BAIRD, Bruce. Butô: dança da diferença. Ephemera, Ouro Preto, v. 2, n. 2, 2019. p. 1-8. Disponível em: https://periodicos.ufop.br/ephemera/article/view/2221/1679. Acesso em: 25/08/2020.

BEETHOVEN, Ludwig van. Sonata para piano n. ${ }^{\circ} 14$ Op. 27 n.․․ 2 [1801]. Disponível em: https://www.youtube.com/watch?v=YO7D6VRITo0. Acesso em: 21 ago. 2021.

BOCCI, Diego Segobia. Bairro da Liberdade e a imigração japonesa: a ideia de Bairro Japonês. Cordis: Revista Eletrônica de História Social da Cidade, n. 2, 2009. Disponível em: https://revistas. pucsp.br/index.php/cordis/article/view/9526.

CANCLINI, Néstor García. Culturas híbridas: estrategias para entrar y salir de la modernidad. Buenos Aires: Sudamericana, 1995.

\footnotetext{
${ }^{18}$ Conta o mito da criação do mundo yorubá, que Olodumaré deu a Obatalá um punhado de areia, que deveria ser jogado sobre a água e encarregou a uma galinha d'angola a missão de espalhar as sementes dando origem as porções de terra. "É por intermédio da galinha-d'angola que o candomblé existe e se reproduz" (ODÉ KILEUY; VERA DE OXAGUIÃ, 2018, p. 112).
} 
CANEVACCI, Massimo. Transculturalidade, interculturalidade e sincretismo. Concinnitas, v. 1, n. 14, p. 139-143, 2009.

CARBOGIM, Bárbara de Souza. Por uma poética política: tensões entre corpo e presença na dança de Tatsumi Hijikata. 2016. 114 f. Dissertação (Mestrado em Artes Cênicas) - Instituto de Filosofia, Artes e Cultura, Universidade Federal de Ouro Preto, Ouro Preto, 2016.

CARVALHO, Francione Oliveira; ASSUNÇÃO, Matheus; DA SILVA, Karina Pereira. A produção visual de novos artistas afrodescendentes no Brasil e reverberações na formação docente em artes visuais. Aurora: revista de arte, mídia e política, v. 12, n. 36, p. 95-113, 2020. Disponível em: https://revistas.pucsp.br/index.php/aurora/article/view/45288.

CASTRO, Eduardo Viveiros de. Os pronomes cosmológicos e o perspectivismo ameríndio. Mana, v. 2, p. 115-144, 1996. Disponível em: https://doi.org/10.1590/S0104-93131996000200005. Acesso: 09/07/2021.

CUNHA, Andrei dos Santos. A cultura japonesa e a imaginação da catástrofe. Sessão de artigos do website da Fundação Japão. Ensaio publicado em 5 de agosto de 2020. Disponível em: https://fjsp.org.br/estudos-japoneses/wp-content/uploads/sites/3/2020/08/texto-andrei-cunha-v4laranja.pdf. Acesso: 09/09/2021.

DELEUZE, Gilles. Diferença e repetição. Rio de Janeiro: Graal, 2006.

DELEUZE, Gilles. Espinosa e o problema da expressão. São Paulo: Editora 34, 2017.

FANON, Frantz. Pele negra, máscaras brancas. Salvador: EDUFBA, 2008.

GREINER, Christine. O colapso do corpo a partir do ankoku butô de Hijikata Tatsumi. Issuu, 2005.

Disponível em: https://www.japonartesescenicas.org/ankokubutoh.pdf. Acesso em: 14 setembro 2020.

HIJIKATA, Tatsumi. Kinjiki - Cores Proibidas. Espetáculo de dança. Com Tatsumi Hijikata e Yoshito Ohno. Estreia em Tóquio, 1959.

HIJIKATA, Tatsumi. Wind Daruma. TDR, v. 44, n. 1, p. 71-81, Spring, 2000. (Tradução para português feita pelos autores). Disponível em: https://chokohma.files.wordpress.com/2014/09/hijikata-words.pdf. Acesso em: 13/09/2021

KATZ, Helena. Que mistério tem esses japoneses. O Estado de S. Paulo, São Paulo, 05 de abr. de 1988. Disponível em: http://www.helenakatz.pro.br/interna.php?id=9. Acesso em: 21 ago. 2021.

KRENAK, Ailton. Como adiar o fim do mundo - Ailton Krenak. Vídeo no YouTube. Disponível em: https://www.youtube.com/watch?v=4NLcCm9bGrs\&feature=youtu.be. Acesso em: 14 setembro 2020.

KUSUNU, Takao; OGAWA, Felícia. O olho do tamanduá. Gomuñiquetan. Versão dia 19-04 - Parte 1/2. Youtube, 2008. 1 vídeo (6 min 50). Disponível em:

https://www.youtube.com/watch?v=c9FSAq7O7QM. Acesso em: 21 ago. 2021

KUSUNU, Takao; OGAWA, Felícia. O olho do tamanduá. Gomuñiquetan. Versão dia 19-04 - Parte 2/2. Youtube, 2008. 1 vídeo (6 min.57). Disponível em:

https://www.youtube.com/watch?v=Rf3y6bxorXg. Acesso em: 21 ago. 2021.

MBEMBE, Achille. Necropolítica. Trad. Renata Santini. São Paulo: n-1, 2018.

MELLO, Simone Martins. Flutuações do butoh no corpo do artista que dança: poéticas da Mestiçagem. 2013. 150f. Dissertação (Mestrado em Dança) - Programa de Pós-Graduação em Dança, Universidade Federal da Bahia, Salvador/BA, 2013.

MISHIMA, Yokio. Cores Proibidas. Trad. de Jefferson José Teixeira. São Paulo: Cia das Letras, 2002.

MUNANGA, Kabengele. Arte Afro-brasileira: O que é afinal? In: AGUILAR, Nelson (org.). Mostra do Descobrimento: Arte Afro-brasileira. São Paulo: Associação Brasil 500 Anos Artes Visuais, 2000.

MUNANGA, Kabengele. Rediscutindo a mestiçagem no Brasil: identidade nacional versus identidade negra. Petrópolis: Vozes, 1999.

NASCIMENTO, Abdias do. O genocídio do negro brasileiro. Rio de Janeiro: Paz e Terra, 1978. 
NASCIMENTO, Beatriz. O conceito de quilombo e a resistência cultural negra. In: RATTS, Alex. Eu sou atlântica: sobre a trajetória de vida de Beatriz Nascimento. São Paulo: Imprensa Oficial, 2006.

ODÉ KILEUY; VERA DE OXAGUIÃ. O candomblé bem explicado: nações Bantu, lorubá e Fon. Rio de Janeiro: Pallas, 2018.

OHNO, Kazuo. Treino e $(m)$ poema. Trad. Tae Suzuki. São Paulo: n-1 Edições, 2016.

OHNO, Yoshito. Corpo em risco. Entrevista à Inês Bogéa. Folha de S. Paulo, Caderno llustrada, São Paulo, quinta-feira, 31 de julho de 2003. Disponível em:

https://www1.folha.uol.com.br/fsp/ilustrad/fq3107200318.htm. Acesso em: 02 set. 2021.

OLIVEIRA, Erika Carolina Cunha Rizza de. Diálogos entre o butô e a Dança Pessoal. Dissertação de mestrado. Instituto de Artes. Campinas: Universidade Estadual de Campinas, 2009.

PERETTA, Éden. Diásporas do Corpo de Carne. Ephemera, Ouro Preto, v. 2, n. 2, p. III-VI, 2019.

Disponível em: https://periodicos.ufop.br/ephemera/article/view/2220/1678. Acesso em: 21 ago. 2021.

PERETTA, Éden. O soldado nu: raízes da dança butô. São Paulo: Perspectiva, 2015.

PONZIO, Ana Francisca. Cristianismo dá inspiração a Kazuo Ohno. Folha de S. Paulo, Caderno llustrada, São Paulo, 21 de maio de 1997.

PRANDI, Reginaldo. Mitologia dos Orixás. São Paulo: Companhia das Letras, 2003.

RIBEIRO, Darcy. O povo brasileiro: a formação e o sentido de Brasil. 2ª ed. São Paulo: Companhia das Letras, 1995.

SERRES, Michel. Filosofia mestiça: le tiers-instruit. Tradução de Maria Ignez Duque Estrada. Rio de Janeiro: Nova Fronteira, 1993.

SERRES, Michel. Novas tecnologias e sociedade pedagógica. Interface, Botucatu, v. 4, n. 6, p. 129142, Feb. 2000.

SHIMADA, Toshio. O que significa a folha Momiji nas tatuagens japonesas? Webpage. Postagem em 10/09/2020. Disponível em: https://toshioshimada.com/2020/09/10/o-que-significa-a-folha-momiji\%E7\%B4\%85\%E8\%91\%89-nas-tatuagens-japonesas/. Acesso: 20/09/2021

SUZUKI, Teiiti. A imigração japonesa no Brasil. Revista do Instituto de Estudos Brasileiros, n. 39, p. 57-65, 1995.

UNO, Kuniichi. A gênese do corpo desconhecido. São Paulo: n-1 Edições, 2012.

UNO, Kuniichi. Hijikata Tatsumi: Pensar um Corpo Esgotado. São Paulo: n-1 edições, 2018.

WEIR, Lucy. Abject Modernism: The Male Body in the Work of Tatsumi Hijikata, Günter Brus and Rudolf Schwarzkogler'. Tate Papers, n. 23, Spring 2015. Disponível em:

https://www.tate.org.uk/research/publications/tate-papers/23/abject-modernism-the-male-body-in-thework-of-tatsumi-hijikata-gunter-brus-and-rudolf-schwarzkogler.Acesso em: 21 ago. 2021.

WIKIDANÇA.NET. Tatsumi Hijikata. Verbete de enciclopédia digital. Disponível em:

http://www.wikidanca.net/wiki/index.php/Tatsumi_Hijikata. Acesso: 20/09/2021.

XAVIER, Marco. Correspondência eletrônica sobre o butô entre Marco Xavier, Flávio Tonnetti, Sandra Corradini e Simone Mello. Destinatário: Núcleo Cuerpo Fluctuante. Ouro Preto, 20 jun. 2020.

XAVIER, Marco. Pequenos sonhos de folhas vermelhas. Disponível em:

https://www.youtube.com/watch?v=PowGBrBgBN4. Acesso em: 31 ago. 2020.

YOKOYAMA, Ana Cristina. O campo onde brotou o butoh: antes do filho, o pai. In: Anais do IV

Encontro de Pós-Graduandos em Estudos Japoneses, Anais. São Paulo: FFLCH/USP, 2018. 